\title{
Halogenated indoles eradicate bacterial persister cells and biofilms
}

\author{
Jin-Hyung Lee ${ }^{1 \dagger}$, Yong-Guy Kim ${ }^{1 \dagger}$, Giyeon Gwon ${ }^{1 \dagger}$, Thomas K. Wood ${ }^{2}$ and Jintae Lee ${ }^{1 *}$
}

\begin{abstract}
The emergence of antibiotic resistance has necessitated new therapeutic approaches to combat recalcitrant bacterial infections. Persister cells, often found in biofilms, are metabolically dormant, and thus, are highly tolerant to all traditional antibiotics and represent a major drug resistance mechanism. In the present study, 36 diverse indole derivatives were investigated with the aim of identifying novel compounds that inhibit persisters and biofilm formation by Gram-negative Escherichia coli and Gram-positive Staphylococcus aureus. 5-lodoindole and other halogenated indoles, 4-fluoroindole, 7-chloroindole, and 7-bromoindole, eradicated persister formation by E. coli and S. aureus, and 5-iodoindole most potently inhibited biofilm formation by the two bacteria. Unlike other antibiotics, 5 -iodoindole did not induce persister cell formation, and 5-iodoindole inhibited the production of the immune-evasive carotenoid staphyloxanthin in S. aureus; hence, 5-iodoindole diminished the production of virulence factors in this strain. These results demonstrate halogenated indoles are potentially useful for controlling bacterial antibiotic resistance.
\end{abstract}

Keywords: Antibiotic resistance, Biofilms, Escherichia coli, Indoles, Persisters, Staphylococcus aureus

\section{Introduction}

The long-term use of bactericidal and bacteriostatic antibiotics has generated multidrug resistant pathogens, such as, Staphylococcus aureus (Levy and Marshall 2004; Cegelski et al. 2008), and resulted in a public health crisis. Of the various mechanisms of antibiotic resistance, the formation of bacterial persisters and biofilms are interlinked and difficult to control (Lewis 2007, 2008). Therefore, a non-antibiotic strategy, which targets persisters and biofilms, is required to control bacterial infections.

Unlike drug resistant cells, which grow in the presence of antibiotics due to genetic changes (Lewis 2010), persister cells are metabolically dormant cells and highly tolerant of antibiotics without undergoing any genetic change (Wood et al. 2013; Keren et al. 2004), and account for a maximum of $\sim 1 \%$ of cells in the stationary phase and in biofilms (Lewis 2007, 2008). However, little is known about the signals and pathways leading

\footnotetext{
${ }^{*}$ Correspondence: jtlee@ynu.ac.kr

${ }^{\dagger}$ Jin-Hyung Lee, Yong-Guy Kim and Giyeon Gwon contributed equally to this work

${ }^{1}$ School of Chemical Engineering, Yeungnam University,

Gyeongsan 38541, Republic of Korea

Full list of author information is available at the end of the article
}

to persister formation, although toxin/antitoxin systems appear to constitute a primary mechanism, as they can be used to induce a state of dormancy (Lewis 2008; Wang and Wood 2011).

Bacterial biofilms are sessile microbial communities that attach to surfaces using self-produced extracellular polymeric substances, such as, polysaccharides, proteins, and nucleic acids. Due to their high antimicrobial tolerances, biofilms formed by pathogenic bacteria pose serious problems to human health, for example, pathogenic $P$. aeruginosa, $C$. albicans, and E. coli biofilms are believed to be causative agents of cystic fibrosis, prostatitis, periodontitis, and urinary catheter cystitis (Costerton et al. 1999). Biofilms protect significant numbers of persister cells from antibiotics and immune systems (Lewis 2008), and thus, biofilms and persisters are closely related. Furthermore, a significant amount of biofilm research has been undertaken with the aim of discovering non-toxic compounds that can inhibit biofilm formation without allowing bacteria to develop drug resistance.

Indole is produced by a large number of Gram-positive and Gram-negative bacterial species, including E. coli (Lee and Lee 2010), and as an interspecies and interkingdom signaling molecule, indole plays important roles 
in various bacterial phenotypes and even in eukaryotic immunity (Bansal et al. 2010; Lee et al. 2010; Vega et al. 2012; Erb et al. 2015). In particular, indole has been reported to modulate biofilm formation in various bacteria (Lee et al. 2007; Oh et al. 2012; Lee et al. 2015) and persister formation in E. coli (Vega et al. 2012, 2013; Hu et al. 2015; Kwan et al. 2015). Of note, functional groups on the indole moiety control biofilm formation (Lee et al. 2009), the production of virulence factors and antibiotic resistance in Pseudomonas aeruginosa (Lee et al. 2009, 2012), spore maturation in Paenibacillus alvei (Kim et al. 2011), and the production of immune-evasive staphyloxanthin in S. aureus (Lee et al. 2013). Therefore, because the demonstrated potential efficacies of indole derivatives against several bacteria, we reasoned that some indole derivatives would have greater anti-persister activities than indole itself.

In the present study, we investigated diverse indole derivatives in an attempt to identify halogenated indoles that inhibit persister formation and biofilm formation by Gram-negative E. coli and Gram-positive S. aureus.

\section{Materials and methods}

\section{Bacterial strains, reagents and strain maintenance}

The following bacterial strains were used in the study; $E$. coli K-12 BW25113, E. coli O157:H7 (86-24), methicillin-sensitive $S$. aureus ATCC 6538, methicillin-resistant S. aureus ATCC 33591 and ATCC BAA-1707, and Pseudomonas aeruginosa PAO1. E. coli BW25113 strain was chosen to compare the efficacy of indoles to the previous results of E. coli persister cells (Hu et al. 2015; Kwan et al. 2015). In addition, three human pathogens, such as Gram-negative E. coli $\mathrm{O} 157: \mathrm{H} 7$ and P. aeruginosa and Gram-positive $S$. aureus were investigated to understand the general efficacy of indoles in the eradication of persister cells. All experiments were conducted at $37{ }^{\circ} \mathrm{C}$, and bacteria were cultured in Luria-Bertani (LB) medium. Indole, thirty-five commercially available indole derivatives (Fig. 1), and three antibiotics were purchased from Sigma-Aldrich (St. Louis, USA) or Combi-Blocks, Inc. (San Diego, USA). The chemical structures of these derivatives are shown in Fig. 1. All indole derivatives were dissolved in dimethyl sulfoxide (DMSO), which was also used as a control. Bacteria were initially streaked from $-80{ }^{\circ} \mathrm{C}$ glycerol stock on LB plates and fresh single colonies were inoculated in LB $(25 \mathrm{~mL})$ in $250 \mathrm{~mL}$ flasks and cultured at $37^{\circ} \mathrm{C}$ at $250 \mathrm{rpm}$. For cell growth measurements, optical densities with or without indoles were measured at $600 \mathrm{~nm}$ using a spectrophotometer (Optizen 2120UV, Mecasys, Korea). Experiments were performed using at least three independent cultures.

\section{Minimum inhibitory concentration (MIC) assay}

The MICs of indoles for E. coli BW25113, S. aureus ATCC 6538, a methicillin-resistant $S$. aureus ATCC 33591, and $P$. aeruginosa PAO1 were determined by incubating freshly inoculated cultures in LB for $24 \mathrm{~h}$ containing varying concentrations of indoles and observing growth inhibition based on lack of turbidity. Results were confirmed by CFU counting. Experiments were performed using at least two independent cultures.

\section{Persister cell killing assay}

Persister cell survival was determined by counting the number of colonies that grew on solid media after washing and serially diluting cells exposed to antibiotics, as previously described (Kwan et al. 2013). Briefly, overnight cultures $(16 \mathrm{~h})$ were diluted 1:1000 with fresh LB medium and grown to the desired turbidity $(0.8$ at $600 \mathrm{~nm}$ for the exponential phase and 3-4 at $600 \mathrm{~nm}$ for the mid-stationary phase) at $250 \mathrm{rpm}$. Since pretreatments of bacteriostatic rifampicin (Kwan et al. 2013) and bactericidal ampicillin and ciprofloxacin (Hu et al. 2015; Kwan et al. 2015) increased persister cell formation, the three antibiotics have been used in this study. In order to obtain antibiotic-induced persister cultures in buffered LB, cultures were exposed to rifampicin $\left(100 \mu \mathrm{g} \mathrm{m} \mathrm{m}^{-1}\right)$, ampicillin $\left(100 \mu \mathrm{g} \mathrm{mL}^{-1}\right)$, or ciprofloxacin $\left(0.5 \mu \mathrm{g} \mathrm{mL}^{-1}\right)$ and incubated for $30 \mathrm{~min}$ at $37^{\circ} \mathrm{C}$. Cells were harvested by centrifugation at $4000 \mathrm{rpm}$ for $14 \mathrm{~min}$ and washed with fresh LB (turbidity was controlled as 0.5$)$. Cells $(0.5 \mathrm{~mL})$ were then transferred to micro-tubes and treated with or without indoles and incubated for $3 \mathrm{~h}$ at $37^{\circ} \mathrm{C}$ at $250 \mathrm{rpm}$. DMSO was used as a control. Cell viabilities were determined by serially diluting cells with PBS buffer, plating $100 \mu \mathrm{L}$ drops on LB agar, and counting colonies.

\section{Persister formation induced by antibiotics, indole, and 5 -iodoindole}

In order to test the effect of 5-iodoindole on persister formation, overnight cultures of E. coli BW25113 or S. aureus 6538 were diluted 1:1000 with $25 \mathrm{~mL}$ of LB and incubated at $37^{\circ} \mathrm{C}$ with shaking at $250 \mathrm{rpm}$ to a turbidity of 0.8 at $600 \mathrm{~nm}$. Cells were then treated with indole (2 mM), 5-iodoindole (2 mM), ampicillin $\left(100 \mu \mathrm{g} \mathrm{m}^{-1}\right)$ or rifampicin $\left(100 \mu \mathrm{g} \mathrm{mL}{ }^{-1}\right)$ and incubated at $37^{\circ} \mathrm{C}$ with shaking at $250 \mathrm{rpm}$ for $0,0.5,1$, or $3 \mathrm{~h}$. Cell viabilities were determined by serial dilution in PBS buffer, plating $100 \mu \mathrm{L}$ drops on LB agar, and counting colonies. DMSO was used as a negative control.

\section{Crystal-violet biofilm assay}

Crystal-violet biofilm assays were performed in 96-well polystyrene plates (SPL Life Sciences, Korea), as previously described (Lee et al. 2011). Briefly, overnight 
cultures were inoculated into LB medium (total volume $300 \mu \mathrm{L}$ ) at an initial turbidity of 0.05 at $600 \mathrm{~nm}$ and cultured with or without indoles for $24 \mathrm{~h}$ without shaking at $37{ }^{\circ} \mathrm{C}$. To quantify biofilm formation, cell cultures were washed three times with $\mathrm{H}_{2} \mathrm{O}$ to remove non-adherent cells. Biofilms were stained with $0.1 \%$ crystal violet for 20 min, rinsed three times with $\mathrm{H}_{2} \mathrm{O}$, extracted with 95\% ethanol, and absorbances were measured at $570 \mathrm{~nm}$. Results are the averages of at least twelve replicate wells.

\section{Confocal laser scanning microscopy and COMSTAT analysis} Escherichia coli BW25113 and S. aureus cells were cultured in 96-well polystyrene plates (SPL Life Sciences, Korea) without shaking with or without 5-iodoindole. Biofilms were stained with carboxyfluorescein diacetate succinimidyl ester (Invitrogen, Molecular Probes, Inc., Eugene, OR, USA) (Weston and Parish 1990). Planktonic cells were removed by washing with PBS three times, and static biofilms were visualized by excitation using an $\mathrm{Ar}$ laser $488 \mathrm{~nm}$ (emission wavelengths 500-550 nm) under a confocal laser microscope (Nikon Eclipse Ti, Tokyo) using a $20 \times$ objective (Kim et al. 2012). Color confocal images were constructed using NIS-Elements $C$ version 3.2 (Nikon eclipse). For each experiment, at least 10 random positions in two independent cultures were chosen for microscopic analysis.

To quantify biofilm formation, color confocal images (20 image stacks) were converted to gray scale using ImageJ. COMSTAT biofilm software (Heydorn et al. 2000) was used to determine biomasses $\left(\mu \mathrm{m}^{3} \mu \mathrm{m}^{-2}\right)$, mean thicknesses $(\mu \mathrm{m})$, and substratum coverages (\%). Thresholding value was fixed for all image stacks, and at least 4 positions and 20 planar images per position were analyzed.

\section{Staphyloxanthin assay}

The production of $S$. aureus staphyloxanthin, which has a golden color, was assayed as previously described (Lee et al. 2013). Briefly, cells of a methicillin-sensitive $S$. aureus ATCC 6538 or of a methicillin-resistant $S$. aureus ATCC BAA-1707, were inoculated at 1:100 dilution in trypticase soy broth $(2 \mathrm{~mL})$ and incubated for $24 \mathrm{~h}$ with indole derivatives at $37{ }^{\circ} \mathrm{C}$ in $14 \mathrm{~mL}$ tubes at $250 \mathrm{rpm}$. Cells $(1 \mathrm{~mL})$ were then collected by centrifugation at $16,600 \times g$ for $10 \mathrm{~min}$, and cell pellets were photographed to compare staphyloxanthin production.

\section{Transmission electron microscope (TEM) assay}

Morphological changes of E. coli and S. aureus after antibiotic rifampicin and 5-iodoindole treatment were examined as previously described with some modification (Kim et al. 2011). As mentioned above, bacteria were exposed to rifampicin $\left(100 \mu \mathrm{g} \mathrm{mL}^{-1}\right)$ and incubated for
$30 \mathrm{~min}$ at $37{ }^{\circ} \mathrm{C}$, washed, and exposed to 5-iodoindole $(2 \mathrm{mM})$ for $1 \mathrm{~h}$ at $37^{\circ} \mathrm{C}$ and $250 \mathrm{rpm}$. Cells were then fixed initially with an aldehyde mixture of $50 \%$ glutaraldehyde and $35 \%$ formaldehyde, incubated at $4{ }^{\circ} \mathrm{C}$ overnight, collected by centrifugation, then fixed with $1 \%$ osmium tetroxide overnight at $4{ }^{\circ} \mathrm{C}$, and washed three times. Cell pellets were mixed with $3 \%$ agarose and sliced to desired sizes, and slices were dehydrated and embedded in an Epon resin mixture (Hatfield, USA). Slices containing embedded cells were then sectioned using a MT-X ultramicrotome (Tucson, USA), loaded onto TEM copper grids, stained with uranyl acetate, and treated with lead citrate. Scanning electron microscopy was performed using a H-7600 electron microscope (Hitachi, Tokyo) at $80 \mathrm{keV}$.

\section{Total mRNA isolation}

Total mRNA was used to study the effects of indole and 5-iodoindole on mRNA synthesis. Briefly, E. coli BW25113 was inoculated into $25 \mathrm{~mL}$ of LB medium in $250 \mathrm{~mL}$ shake flasks at a starting turbidity of 0.005 at $600 \mathrm{~nm}$ and grown to a turbidity of 0.8 . Cultures were then exposed to rifampicin $\left(100 \mu \mathrm{g} \mathrm{mL}^{-1}\right)$ for $30 \mathrm{~min}$ at $37{ }^{\circ} \mathrm{C}$ with shaking at $250 \mathrm{rpm}$ to create persister cells (Kwan et al. 2013), washed with fresh LB, and incubated in the presence or absence of indole or 5-iodoindole $(2 \mathrm{mM})$ for $1 \mathrm{~h}$. RNase inhibitor (RNAlater, Ambion, TX, USA) was added to prevent RNA degradation. Total RNA was isolated using a Qiagen RNeasy mini Kit (Valencia, CA, USA). At least two independent cultures were performed per experiment.

\section{Results}

Indoles kill E. coli persister cells

Since indole has been reported to modulate the survival of E. coli persister cells (Vega et al. 2012; Hu et al. 2015; Kwan et al. 2015), we investigated the abilities of indole and 35 commercially available indole derivatives at a concentration of $2.0 \mathrm{mM}$ to reduce the survival of $E$. coli K-12 BW25113 persister cells. For initial screening, E. coli cells were treated with rifampicin $\left(100 \mu \mathrm{g} \mathrm{mL} \mathrm{m}^{-1}\right)$ to convert exponentially growing cells to persister cells (Kwan et al. 2013). As shown previously (Kwan et al. 2013), rifampicin pretreatment increased persister cell levels to $40 \pm 14 \%$ (Fig. 1). After rifampicin treatment, indole at $2.0 \mathrm{mM}$ reduced persister survival from 40 to $11 \%$, which concurred with previous reports ( $\mathrm{Hu}$ et al. 2015; Kwan et al. 2015). More importantly, indole derivatives demonstrated a wide range of inhibitory abilities to kill persister cells (Fig. 1). Of the tested compounds, five halogenated indoles, namely, 5-iodoindole, 4-fluoroindole, 5-(trifluoromethoxy)indoline-2,3-dione, 7-chloroindole, and 7-bromoindole reduced E. coli K-12 BW25113 


\begin{tabular}{|c|c|c|c|c|c|c|c|c|}
\hline Name & Structure & Survival \% & Name & Structure & Survival \% & Name & Structure & Survival \% \\
\hline None & & $40 \pm 14$ & 5-Fluoroindole & & $18 \pm 2$ & $\begin{array}{l}\text { 8-Fluoro } \\
\text { quinoline }\end{array}$ & & $45 \pm 5$ \\
\hline $\begin{array}{l}\text { 5-lodoindole } \\
1.0 \mathrm{mM}\end{array}$ & & $\begin{array}{c}0.007 \pm \\
0.009\end{array}$ & Indole-3-carbinol & & $22 \pm 5$ & $\begin{array}{c}\text { 5-bromo-3-iodo- } \\
\text { 7-azaindole }\end{array}$ & & $46 \pm 3$ \\
\hline $\begin{array}{l}\text { 5-lodoindole } \\
2.0 \mathrm{mM}\end{array}$ & & 0 & $\begin{array}{c}\text { 7-(Trifluoro } \\
\text { methyl) indoline } \\
\text {-2,3-dione }\end{array}$ & & $27 \pm 5$ & $\begin{array}{l}\text { Indole-3- } \\
\text { acetic acid }\end{array}$ & & $46 \pm 10$ \\
\hline $\begin{array}{l}\text { 4-Fluoroindole } \\
1.0 \mathrm{mM}\end{array}$ & & $4.7 \pm 2.0$ & 7-Hydroxyindole & & $28 \pm 7$ & 7-Methylindole & & $47 \pm 26$ \\
\hline $\begin{array}{l}\text { 4-Fluoroindole } \\
2.0 \mathrm{mM}\end{array}$ & & 0 & 7-Methoxyindole & & $31 \pm 10$ & $\begin{array}{c}\text { 7-Fluoroindoline } \\
\text {-2,3-dione }\end{array}$ & & $52 \pm 11$ \\
\hline $\begin{array}{l}\text { 5-(trifluoromethoxy) } \\
\text { indoline-2,3-dione }\end{array}$ & & $0.01 \pm 0.01$ & $\begin{array}{l}\text { Indole-3- } \\
\text { acetonitrile }\end{array}$ & & $33 \pm 15$ & $\begin{array}{l}\text { Indole-3- } \\
\text { propionic acid }\end{array}$ & & $52 \pm 11$ \\
\hline 7-Chloroindole & & $0.01 \pm 0.01$ & $\begin{array}{l}\text { 7-Benzyloxy } \\
\text { indole }\end{array}$ & & $34 \pm 3$ & 7-Nitroindole & & $52 \pm 30$ \\
\hline 7-Bromoindole & & $0.02 \pm 0.1$ & 7-Formylindole & & $35 \pm 15$ & 2-Oxindole & & $55 \pm 13$ \\
\hline 7-Fluoroindole & & $1.1 \pm 0.3$ & 7-Azaindole & & $35 \pm 5$ & $\begin{array}{c}\text { Indole-7- } \\
\text { carboxylic acid }\end{array}$ & & $56 \pm 6$ \\
\hline 6-Fluoroindole & & $1.6 \pm 0.1$ & Isatin & & $37 \pm 10$ & $\begin{array}{c}3,3^{\prime}- \\
\text { methylene } \\
\text { bisindole }\end{array}$ & & $56 \pm 13$ \\
\hline Indole & & $11 \pm 1$ & $\begin{array}{c}\text { 1-BOC- } \\
\text { 7-methylindole }\end{array}$ & & $39 \pm 10$ & $\begin{array}{l}\text { Indole-3-butyric } \\
\text { acid }\end{array}$ & & $54 \pm 26$ \\
\hline $\begin{array}{l}\text { Methyl indole-7- } \\
\text { carboxylate }\end{array}$ & & $12 \pm 4$ & $\begin{array}{l}\text { Indole-3- } \\
\text { carboxyaldehyde }\end{array}$ & & $40 \pm 2$ & $\begin{array}{l}\text { 5-fluoroindolin- } \\
\text { 2,3-dione }\end{array}$ & & $56 \pm 2$ \\
\hline 5-Fluoroxiindole & & $14 \pm 2$ & $\begin{array}{l}\text { Indole-3- } \\
\text { acetamide }\end{array}$ & & $41 \pm 4$ & 5,6-difluoroisatin & & $58 \pm 32$ \\
\hline
\end{tabular}

Fig. 1 Indole derivatives kill E. coli persister cells. Escherichia coli K-12 BW25113 cells were exposed to rifampicin (100 $\left.\mathrm{\mu g} \mathrm{mL}^{-1}\right)$ to induce persister cells. Indole or indole derivatives at $2 \mathrm{mM}$ were then administered for $3 \mathrm{~h}$ at $37^{\circ} \mathrm{C}$ and $250 \mathrm{rpm}$, and cell viabilities were determined. All indole compounds were dissolved in DMSO, and DMSO was used as the control (none). For the most active compounds, 5-iodoindole and 4-fluoroindole, two concentrations (1 and $2 \mathrm{mM}$ ) were tested. The experiment was performed in duplicate

persister survival by more than 2000 -fold, whereas other indole derivatives had less impact on persister survival (Fig. 1). In particular, 5-iodoindole and 4-fluoroindole at $2.0 \mathrm{mM}$ completely prevented persister survival, and at $1.0 \mathrm{mM}, 5$-iodoindole was more potent $(0.007 \%$ survival) than 4-fluoroindole (4.7\% survival). Accordingly, 5-iodoindole became the focus of further study.

Further persister assays showed 5-iodoindole dosedependently reduced persister survival and that at a concentration of only $0.2 \mathrm{mM}$ it reduced persister survival by 20 -fold versus the non-treated control (Fig. 2a). Furthermore, 5-iodoindole effectively killed persister cells originally derived from stationary and exponential phase cells (Fig. 2b), and significantly reduced the survival of persisters pretreated with ampicillin and ciprofloxacin (Fig. 2c, d). Specifically, no persister cells (no colonies) were detected after treating ampicillin- or ciprofloxacingenerated persister cells with 5-iodoindole at concentrations $>1.0 \mathrm{mM}$. Since ampicillin and ciprofloxacin are representative of two different classes of bactericidal antibiotics and because rifampicin is a bacteriostatic antibiotic that inhibits mRNA synthesis (Calvori et al. 1965), these findings suggest 5-iodoindole effectively kills persister cells generated by bactericidal antibiotics and bacteriostatic rifampicin.

\section{5-Iodoindole eradicates the persister cells of human pathogens}

The ability of 5-iodoindole to eradicate other human pathogens, that is, enterohemorrhagic E. coli O157:H7 (EHEC), methicillin-sensitive $S$. aureus ATCC 6538 (MSSA 6538), methicillin-resistant S. aureus ATCC 33591 (MRSA 33591), and P. aeruginosa. 5-Iodoindole was found to be effective against EHEC, that is, at $1.0 \mathrm{mM} 5$-iodoindole completely eradicated persister cells (Fig. 3a), and 5-iodoindole dose-dependently reduced MSSA 6538 and MRSA 33591 persister survival (Fig. 3c, d). However, 5-iodoindole at concentrations of 

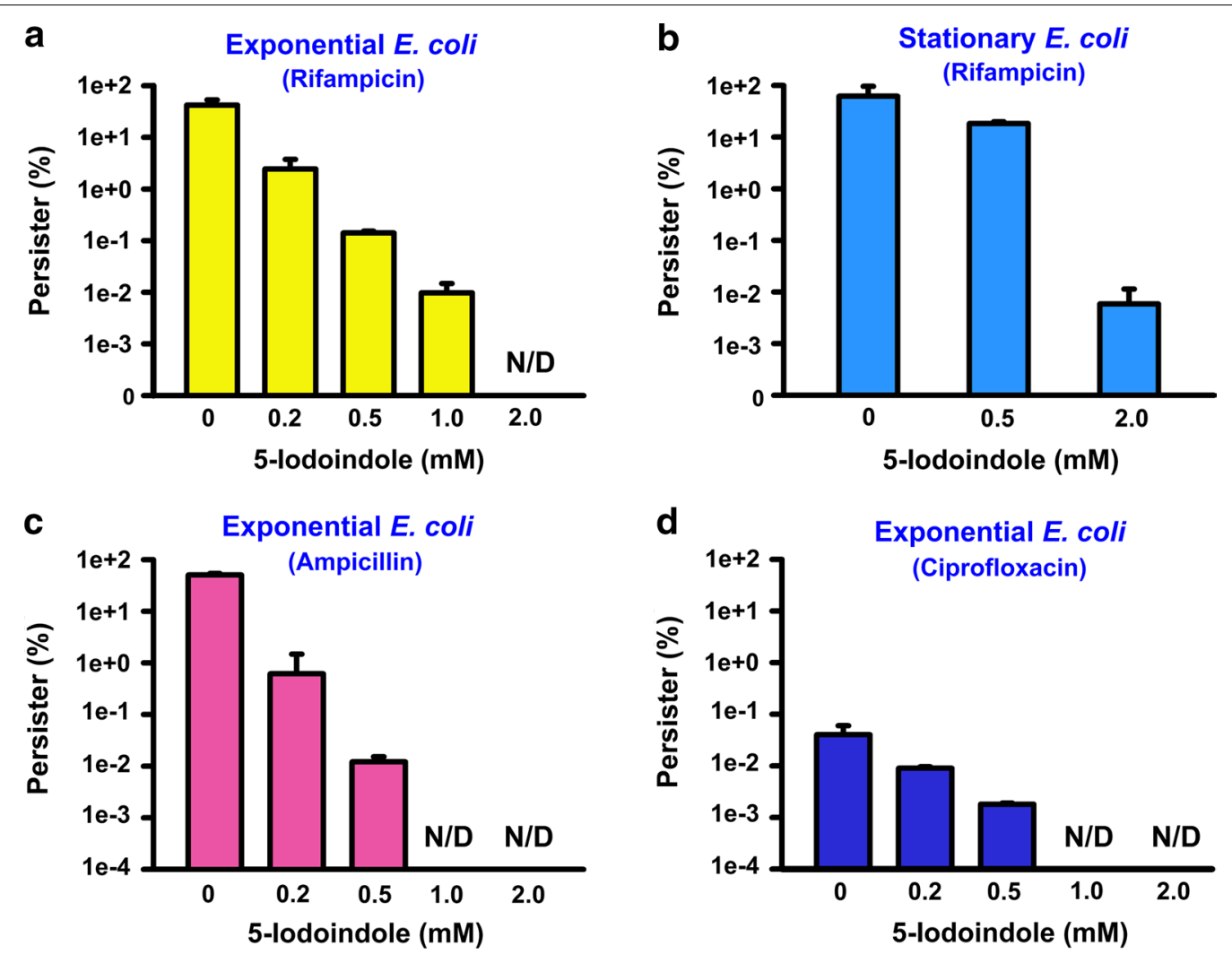

Fig. 2 5-lodoindole eradicates E. coli persister cells. Escherichia coli K-12 BW25113 cells in the exponential growth stage (a) or stationary growth stage $(\mathbf{b})$ were exposed to rifampicin $\left(100 \mu \mathrm{g} \mathrm{mL} \mathrm{L}^{-1}\right)$ to induce persister cells, which were then treated with 5 -iodoindole for $3 \mathrm{~h}$ at $37^{\circ} \mathrm{C}$ and $250 \mathrm{rpm}$. Cell viabilities were determined. Ampicillin at $100 \mathrm{\mu g} \mathrm{mL}^{-1}$ (c) or ciprofloxacin at $0.5 \mathrm{\mu g} \mathrm{mL}^{-1}$ (d) were used to induce persister cells and then 5-iodoindole was treated. The experiment was performed in duplicate. N/D represents eradication below the limit of detection

up to $4 \mathrm{mM}$ did not reduce $P$. aeruginosa persister survival (Fig. 3b).

The minimum inhibitory concentrations (MICs) of halogenated indoles were then measured since general antibiotic treatments were administered at least five times their MICs (Wood 2016) to minimize the survivals of potentially resistant cells. The MICs of 5-iodoindole were between 1.0 and $2.0 \mathrm{mM}$ for $E$. coli and $S$. aureus strains, and the MICs of other indoles (4-fluoroindole, 7-chloroindole, and 7-bromoindole) fell in the range 2.0$3.0 \mathrm{mM}$ (Table 1). Hence, 5 -iodoindole at a concentration of $1 \times$ its MIC level markedly reduced E. coli $\mathrm{K}-12$ and EHEC persister survival, and persister survival of two $S$. aureus strains, including MRSA. Accordingly, E. coli and $S$. aureus strains were the subjects of further study.

5-lodoindole inhibits $E$. coli and S. aureus biofilm formation Since biofilm formation is a major mechanism of bacterial persistence (Costerton et al. 1999) and slow-growing biofilms produce substantial numbers $(\sim 1 \%)$ of persisters (Lewis 2008), we investigated the effects of 5-iodoindole and of other two halogenated indoles on biofilm formation by $E$. coli and $S$. aureus. Of the indoles tested that reduced persister survival, 5-iodoindole most effectively inhibited biofilm formation by $E$. coli and S. aureus and did so in a dose-dependent manner (Fig. 4a, b). For example, 5 -iodoindole at $0.2 \mathrm{mM}(1 / 10$ of $\mathrm{MIC})$ reduced biofilm formation by $E$. coli (88\%) and S. aureus (81\%). In contrast, 4-fluoroindole and 7-chloroindole, at low levels $(0.05-0.2 \mathrm{mM})$ increased biofilm formation by $E$. coli (Fig. 4a), which concurs with previous observations that sub-inhibitory concentrations of antibiotics induce biofilm formation by E. coli, P. aeruginosa, and Staphylococcus epidermidis (Hoffman et al. 2005; Linares et al. 2006; Rachid et al. 2000). In addition, three halogenated indoles did not affect biofilm formation by $P$. aeruginosa at concentrations up to $2 \mathrm{mM}$ (Fig. $4 \mathrm{c}$ ).

Since bacteria form biofilms on the bottoms and sides of plates, confocal laser microscopy was used to observe biofilm formation on the bottoms of 96-well polystyrene plates. In-line with our quantitative data, 5-iodoindole at $0.2 \mathrm{mM}(1 / 10$ of MIC) dramatically inhibited biofilm formation by E. coli and S. aureus (Fig. 4d, e). Also, relative amounts of biofilm formation by $E$. coli and $S$. aureus 

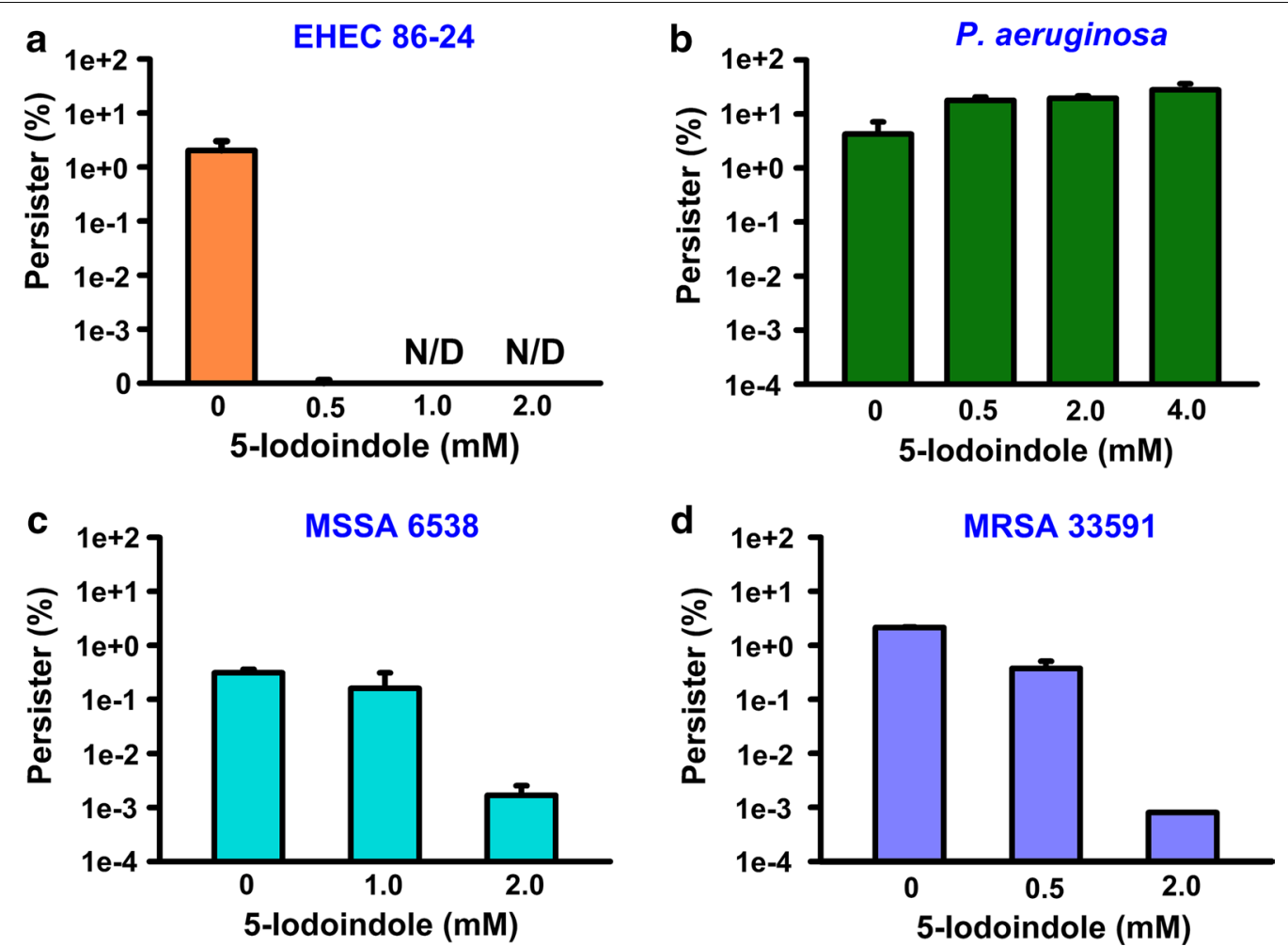

Fig. 3 5-lodoindole kills persister cells of human pathogens. Escherichia coli O157:H7 (EHEC, a), P. aeruginosa (b), methicillin-sensitive S. aureus (MSSA) 6538 (c), or a methicillin-resistant S. aureus (MRSA) 33591 (d) were exposed to rifampicin $\left(100 \mu \mathrm{g} \mathrm{mL}^{-1}\right)$, and then 5-iodoindole was treated for $3 \mathrm{~h}$ at $37^{\circ} \mathrm{C}$ and $250 \mathrm{rpm}$. Cell viabilities were then determined. The experiments were performed in duplicate. N/D represents eradication below the limit of detection

Table 1 MICs of the indoles examined in this study

\begin{tabular}{llllll}
\hline Strain & Indole $(\mathbf{m M})$ & 5-lodoindole $(\mathbf{m M})$ & 4-Fluoroindole $(\mathbf{m M})$ & 7-Chloroindole $(\mathbf{m M})$ & 7-Bromoindole $(\mathbf{m M})$ \\
\hline E. coli BW25113 & 5.0 & 1.5 & 2.0 & 2.0 & 2.0 \\
S. aureus MSSA 6538 & 20 & 2.0 & 3.0 & 3.0 & 3.0 \\
S. aureus MRSA 33591 & 20 & 1.0 & 3.0 & 3.0 & 3.0 \\
P. aeruginosa PAO1 & 10 & $>50$ & 5 & 10 & $>50$ \\
\hline
\end{tabular}

confirmed that S. aureus 6538 produced markedly more biofilm than $E$. coli BW25113 under the same conditions.

Biofilm inhibition was further confirmed by COMSTAT analysis as 5-iodoindole was found to reduce all three measured parameters (biomass, mean thickness, and substratum coverage) of E. coli and S. aureus (Table 2). Specifically, the biomasses (volume/area) of $E$. coli and $S$. aureus biofilms were reduced by $0.2 \mathrm{mM}$ 5 -iodoindole by more than 93 and 59\%, respectively. Generally, cells in the stationary stage or biofilms contain a high population of persisters more than cells in exponential stage. Therefore, these results show 5-iodoindole effectively kills persisters at exponential and stationary stages, and thus, inhibits biofilm formation.

\section{5-lodoindole rapidly kills $E$. coli and S. aureus without forming persister cells}

In addition to the persister cell killing assay, the effects of 5-iodoindole on persister formation were measured without antibiotic pretreatment. As expected (Kwan et al. 2013), the antibiotics ampicillin or rifampicin at high concentrations $\left(100 \mu \mathrm{g} \mathrm{mL} \mathrm{m}^{-1}, 10 \times \mathrm{MIC}\right)$ produced substantial numbers $(1-0.01 \%)$ of persister cells of $E$. coli and $S$. aureus (Fig. 5a, b). However, 5-iodoindole at $2 \mathrm{mM}$ $(\sim 1 \times \mathrm{MIC})$ completely killed all $E$. coli and $S$. aureus 
a E. coli

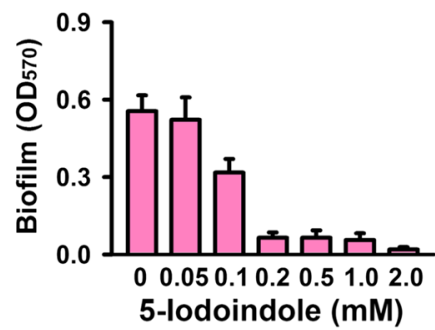

b MSSA 6538

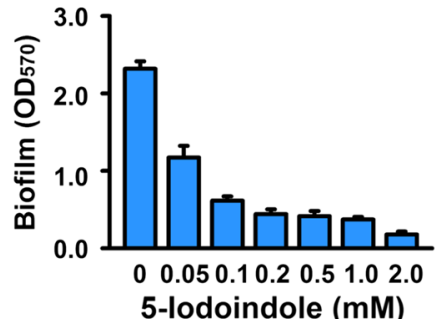

C $P$. aeruginosa

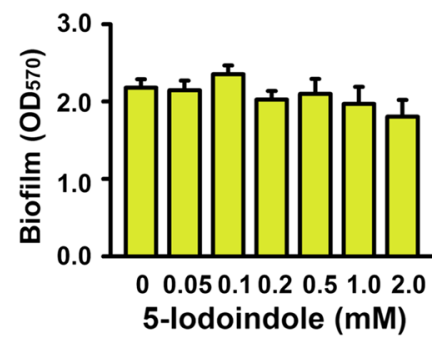

d E. coli
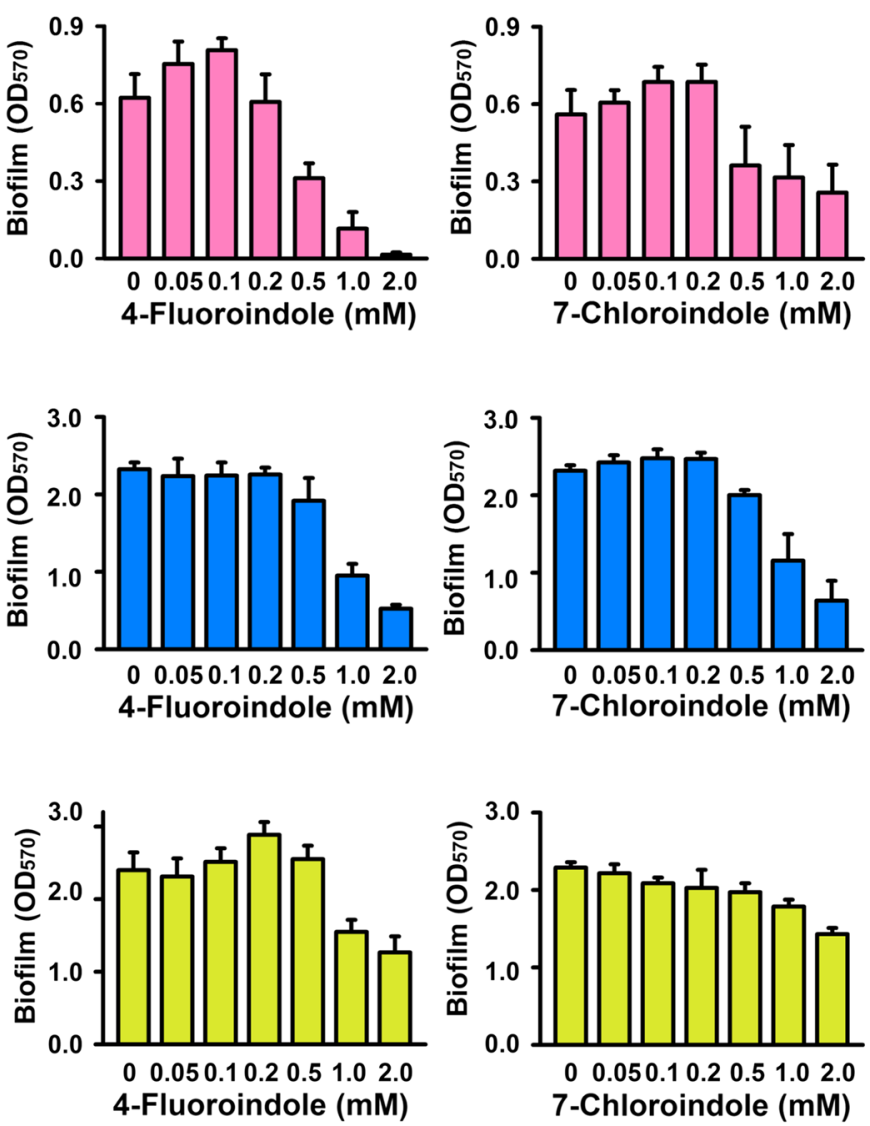

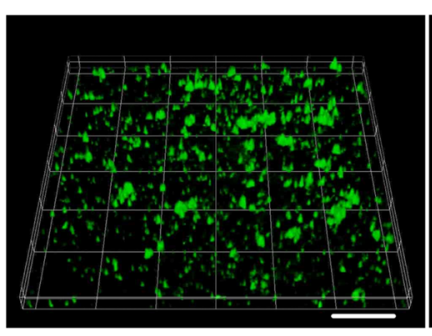

None

e MSSA 6538

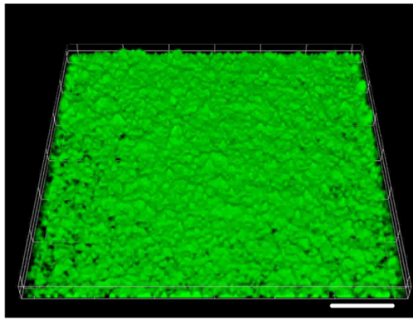

None

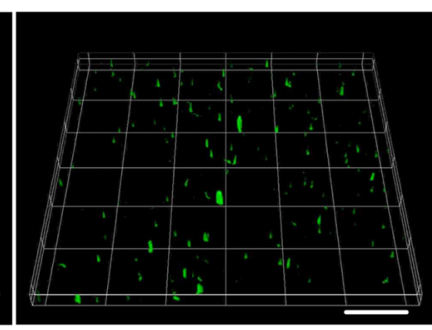

5-lodoindole $0.2 \mathrm{mM}$

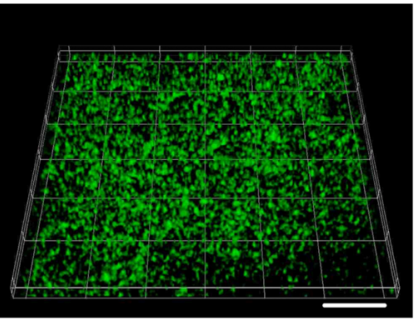

5-lodoindole $0.2 \mathrm{mM}$

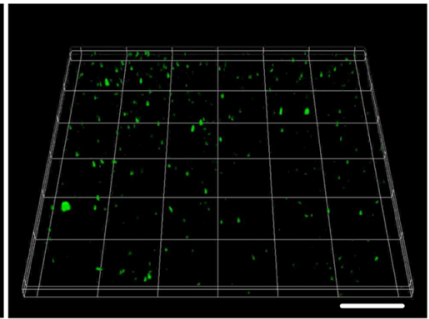

5-lodoindole $\mathbf{0 . 5} \mathbf{~ m M}$

Fig. 4 Substituted indoles reduce the biofilm formation of E. coli and S. aureus. Escherichia coli K-12 BW25113 (a), S. aureus (MSSA) 6538 (b), and P. aeruginosa (c) biofilm formation was quantified after culturing with indoles for $24 \mathrm{~h}$ in 96 -well plates. Error bars indicate SDs. For confocal laser microscope analysis, biofilm formation by E. coli K-12 BW25113 (d) and S. aureus (MSSA) 6538 (e) was observed in 96-well plates in the presence and absence of 5-iodoindole. The scale bars represent $100 \mu \mathrm{m}$. The experiment was performed in triplicate 
Table 2 COMSTAT analysis results for E. coli K-12 BW25113 and S. aureus MSSA 6538 biofilms on 96-well plates in the presence of 5-iodoindole

\begin{tabular}{llccc}
\hline Strain & 5-lodoindole $(\mathbf{m M})$ & Volume/area $\left(\boldsymbol{\mu m}^{\mathbf{3}} \boldsymbol{\mu \mathbf { m } ^ { - \mathbf { 2 } } )}\right.$ & Mean thickness $(\boldsymbol{\mu m})$ & Substratum coverage $(\%)$ \\
\hline E. coli K-12 BW25113 & None & $2.3 \pm 0.6$ & $2.9 \pm 0.7$ & $26 \pm 7$ \\
& 0.2 & $0.15 \pm 0.03$ & $0.20 \pm 0.04$ & $1.4 \pm 0.2$ \\
S. aureus MSSA 6538 & None & $12.6 \pm 0.3$ & $11.6 \pm 0.3$ & $98 \pm 1$ \\
& 0.2 & $5.1 \pm 0.4$ & $5.2 \pm 0.3$ & $51 \pm 6$ \\
& 0.5 & $1.8 \pm 0.8$ & $2.1 \pm 0.9$ & $22 \pm 8$ \\
\hline
\end{tabular}
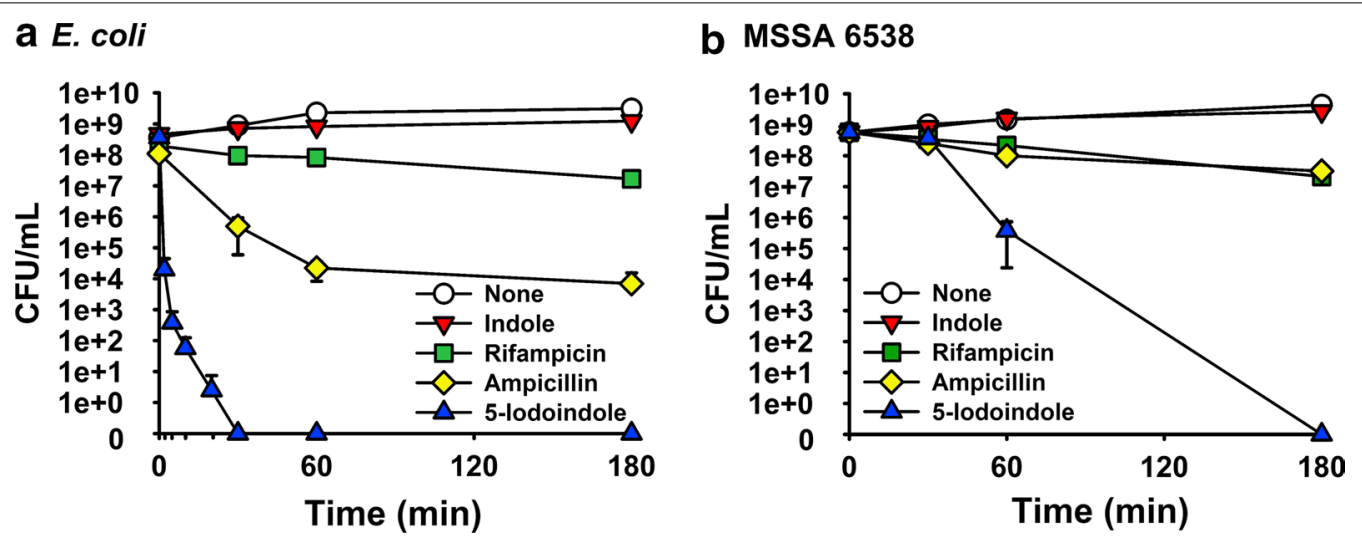

Fig. 5 -lodoindole does not induce E. coli and S. aureus persister cell formation. Exponential-phase cultures of E. coli K-12 BW25113 (a) or S. aureus (MSSA) 6538 (b) were exposed to indole $(2 \mathrm{mM})$, rifampicin $\left(100 \mu \mathrm{g} \mathrm{mL}{ }^{-1}\right)$, ampicillin $\left(100 \mu \mathrm{g} \mathrm{mL}^{-1}\right)$, or 5-iodoindole $\left(2 \mathrm{mM}^{2}\right.$ at $37^{\circ} \mathrm{C}, 250 \mathrm{rpm}$. Cell viabilities were then determined. The experiment was performed in triplicate

cells within $3 \mathrm{~h}$ indicating that 5 -iodoindole do not produce persister cells (Fig. 5a, b). In the case of E. coli, 5-iodoindole eradicated all $E$. coli cells within $30 \mathrm{~min}$. In contrast, indole (the control) at $2 \mathrm{mM}$ did not kill $E$. coli or S. aureus. Hence, these results suggest that killing mechanisms of 5-iodoindole and indole, ampicillin, or rifampicin differ, which should be further investigated.

In order to understand how 5-iodoindole kills persister cells, two other iodo compounds (sodium iodide and potassium iodide) were tested. However, neither compound killed persister cells at all at $2 \mathrm{mM}$ (data not shown). This result shows the iodide ion is not a major factor, but that the iodine within the indole moiety reduces persister survival and imparts antimicrobial activity.

\section{5-lodoindole reduces staphyloxanthin production in S. aureus strains}

Since indole and 7-benzyloxyindole were found to inhibit the production of staphyloxanthin in S. aureus (Lee et al. 2013), we investigated staphyloxanthin production in two S. aureus strains (MSSA 6538 and MRSA ATCC BAA1707). 5-Iodoindole was observed to decrease staphyloxanthin production in a dose-dependent manner (Fig. 6).
More specifically, 5-iodoindole at $0.3 \mathrm{mM}$ (1/10 of MIC) abolished staphyloxanthin production and produced colorless cell pellets of two S. aureus strains. Furthermore, 5-iodoindole was much more potent than indole. Hence, 5-iodoindole also diminishes the virulence of $S$. aureus strains, including a MRSA strain.

\section{5-lodoindole does not alter E. coli and S. aureus cell morphology}

Transmission electron microscopy (TEM) was used to investigate if any morphological changes are induced by 5 -iodoindole. Intriguingly, neither rifampicin $\left(100 \mu \mathrm{g} \mathrm{mL}^{-1}\right)$ nor 5 -iodoindole $(2 \mathrm{mM})$ caused any obvious cell shape or membrane change of E. coli or $S$. aureus (Fig. 7a, b). In the case of rifampicin, this observation was expected because it suppresses cell growth by inhibiting mRNA synthesis (Calvori et al. 1965), and thus, we considered 5-iodoindole might also inhibit mRNA synthesis. To investigate this notion, we isolated the total mRNA of $E$. coli BW25113 cells treated with or without indole or 5 -iodoindole treatment for $0,0.5$, and $1 \mathrm{~h}$. However, neither indole nor 5-iodoindole at concentrations up to $2 \mathrm{mM}$ changed the amount or purity of isolated mRNA. For example, the treatment of indole or 5-iodoindole 


\section{a MSSA 6538}

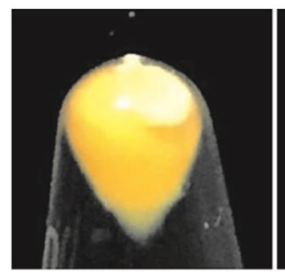

None

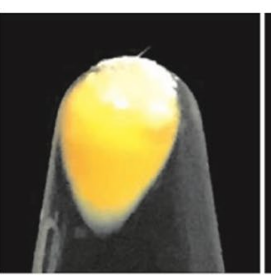

0.1

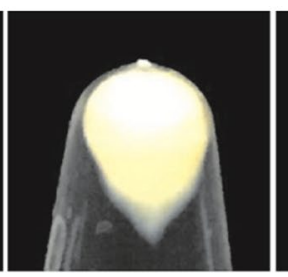

0.2

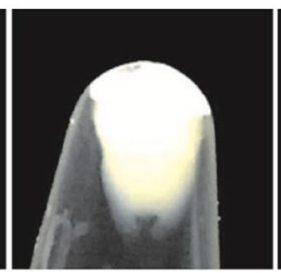

0.3

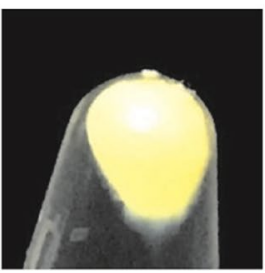

0.3

\section{5-lodoindole (mM)}

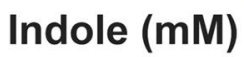

\section{b MRSA BAA-1707}

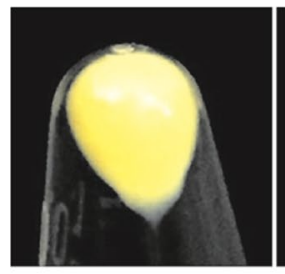

None

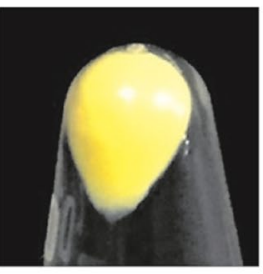

0.1

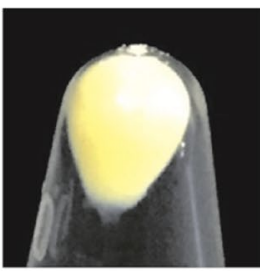

0.2

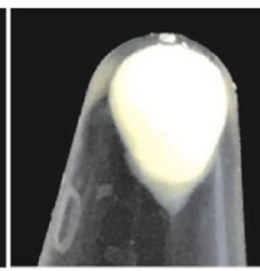

0.3

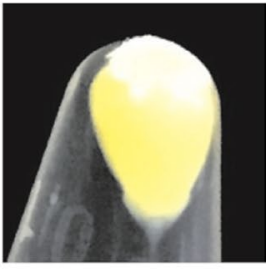

0.3

5-lodoindole (mM)

Fig. 6 5-lodoindole inhibits staphyloxanthin production in S. aureus. Staphyloxanthin production was determined in the cell pellets of S. aureus (MSSA) 6538 (a) or a methicillin-resistant S. aureus (MRSA) ATCC BAA-1707 (MW 2) (b) grown for 24-h in the presence or absence of 5-iodoindole or indole. The experiment was performed in duplicate and representative images are shown

at $2 \mathrm{mM}$ for $1 \mathrm{~h}$ produced $460 \pm 80 \mathrm{ng} \mathrm{\textrm {mL } ^ { - 1 }}(2.11$ at $\left.\mathrm{A}_{260 / 280}\right)$ or $360 \pm 80 \mathrm{ng} \mathrm{mL} \mathrm{m}^{-1}$ (2.10 at $\left.\mathrm{A}_{260 / \mathrm{A} 280}\right)$ of total mRNA, respectively, while no treatment produced $540 \pm 90 \mathrm{ng} \mathrm{mL}^{-1}\left(2.12\right.$ at $\left.\mathrm{A}_{260 / \mathrm{A} 280}\right)$. Hence, it appears that unlike rifampicin, 5-iodoindole does not interfere mRNA synthesis.

\section{Discussion}

The present study was undertaken to identify indole derivatives capable of inhibiting Gram-negative E. coli and Gram-positive $S$. aureus persisters and biofilm formation by these two bacteria. Our results show that the different functional groups of indoles differentially controlled E. coli persistence, and that several halogenated indoles, especially 5-iodoindole, potently inhibit the formation of persister cells and biofilms by $E$. coli and $S$. aureus, but not those of $P$. aeruginosa. In addition, 5 -iodoindole was found to have anti-microbial activities against $E$. coli and $S$. aureus, but unlike other antibiotics, 5-iodoindole does not induce $E$. coli and $S$. aureus persister cell formation. Furthermore, 5-iodoindole reduces the production of the virulence factor staphyloxanthin by S. aureus.

In regard to the chemical structures, the addition of halogen atoms to the indole structure, such as, in 4-fluoroindole, 7-chloroindole, 7-bromoindole, 5-iodoindole, and 5-(trifluoromethoxy)indoline-2,3-dione, was found to markedly reduce persister cell survival (Fig. 1). Elemental halogens are potentially toxic and have high reactivities, and both chlorine and bromine are used as disinfectants for drinking water, swimming pools, wounds, spas, dishes, and surfaces. Iodine is the least reactive of the four common halogens, and the biological toxicity of 5-iodoindole has not been studied previously and warrants additional scrutiny.

Currently, studies have described a number of strategies to combat persister cells, such as, (1) killing persister cells in the dormant state, (2) waking persisters and then applying antibiotics, and (3) preventing the formation of persister cells (Wood 2016). Our results indicate 5-iodoindole can prevent persister formation (Fig. 5) and kill persisters in the stationary phase (Figs. 2, 3), and that it can effectively prevent biofilm formation (Fig. 4). Hence, 5-iodoindole is a potent anti-persister compound in that it can both kill and prevent persister cell formation as well as is effective in biofilms.

Although the substituted indoles effectively killed persister cells of $E$. coli and $S$. aureus, including a MRSA strain, they did not effectively kill $P$. aeruginosa persisters (Fig. 3b) or prevent its formation of biofilms (Fig. 4c). Indole stimulates biofilm formation by $P$. aeruginosa (Lee et al. 2007) and diminishes $P$. aeruginosa virulence (Lee 


\section{a E. coli}

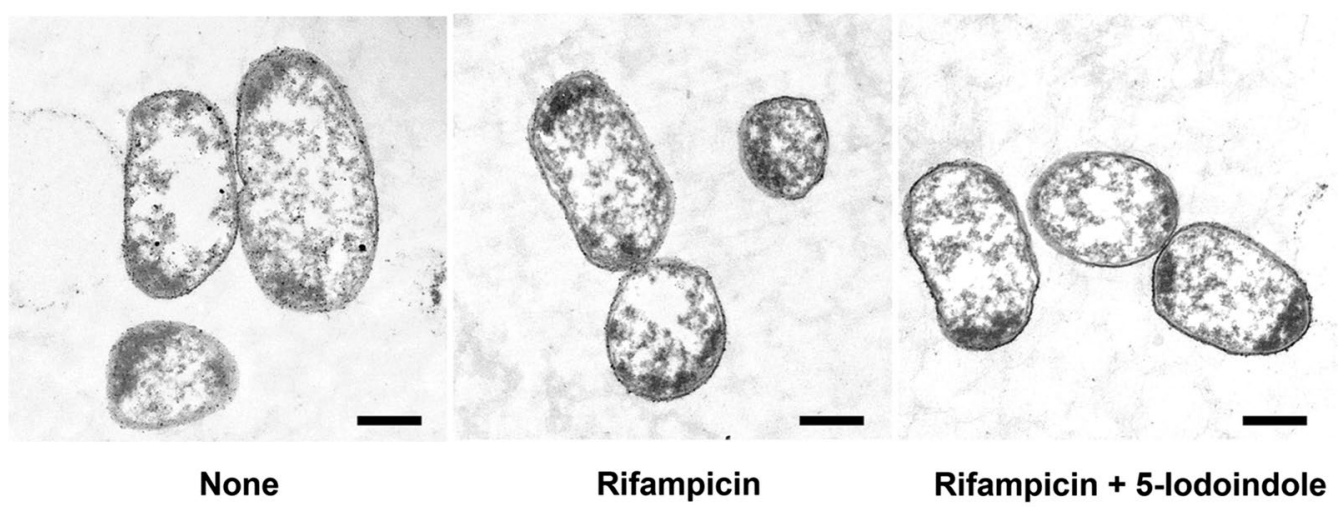

\section{b S. aureus}

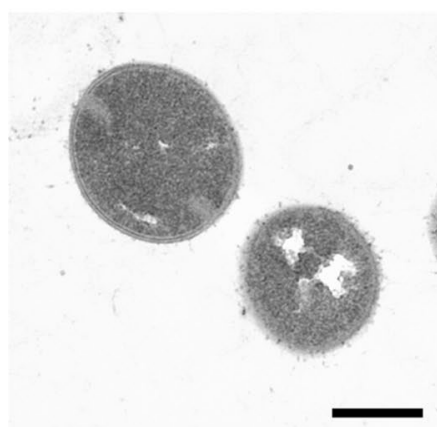

None

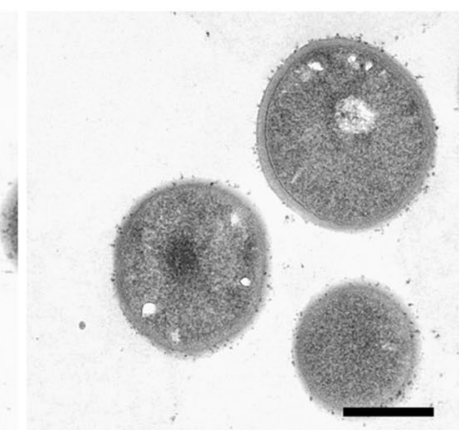

Rifampicin

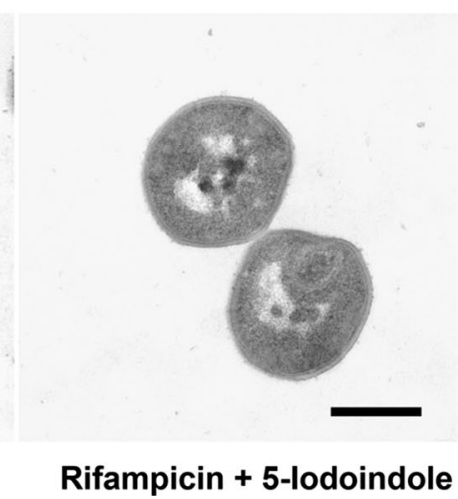

Rifampicin + 5-lodoindole

Fig. 7 5-lodoindole does not affect cell morphology. Exponential-phase cultures of E. coli K-12 BW25113 (a) or S. aureus (MSSA) 6538 (b) were exposure to rifampicin $\left(100 \mathrm{\mu g} \mathrm{mL}^{-1}\right)$ for $30 \mathrm{~min}$ and then incubated with 5 -iodoindole $(2 \mathrm{mM})$ or DMSO for $1 \mathrm{~h}$ then visualized by transmission electron microscopy. The scale bars represent $500 \mathrm{~nm}$

et al. 2009). For the halogenated indoles (4-fluoroindole, 7-chloroindole, 7-bromoindole, and 5-iodoindole), P. aeruginosa had MICs one magnitude higher than E. coli and $S$. aureus (Table 1), but these indoles did not substantially influence biofilm formation (Fig. 4c) or the production of virulence factors (data not shown). Several authors have reported $P$. aeruginosa can resist halogens, such as, chlorine (Seyfried and Fraser 1980), iodine (Brown and Gauthier 1993), and brominated compounds by utilizing its efflux pump (Maeda et al. 2012). Hence, it appears that unlike E. coli and S. aureus, P. aeruginosa has probably developed several resistant mechanisms against halogenated compounds.

Since antibiotics work in different ways, the genetic mechanism responsible for their promotion of persister formation remains elusive, although toxin/antitoxin systems appear to play a role in persister formation (Lewis 2008; Wang and Wood 2011). Several recent reports (Kwan et al. 2013; Conlon et al. 2013; Marques et al. 2014) have suggested protein synthesis (translation) or protein degradation underlie the inhibition of persister cell formation. In the present study, 5-iodoindole did not alter the amount of total mRNA or distinctively change the membrane morphologies of $E$. coli or $S$. aureus (Fig. 7). Thus, we speculate that perturbations of protein synthesis, stability, or protein degradation are responsible, and suggest this possibility be further investigated. Furthermore, our observations indicate that 5-iodoindole could be used in combination with commercial antibiotics to eradicate persister cells and biofilms.

This is the first report to show that halogen-containing indoles should be considered potential agents for the control of persister cells and biofilms. Since hundreds of indole derivatives are commercially available and new indole derivatives are readily constructed (Bunders et al. 2011), further screening of larger libraries of indole derivatives might generate more potent agents for the eradication of human pathogens like pathogenic E. coli and S. aureus. 


\section{Authors' contributions}

$J H L, Y G K$, and GG performed experiments, and analyzed data. TKW and JL conceived of the study. JHL and $J \mathrm{~L}$ designed experiments and wrote the manuscript. All authors read and approved the final manuscript.

\section{Author details}

1 School of Chemical Engineering, Yeungnam University, Gyeongsan 38541, Republic of Korea. ${ }^{2}$ Department of Chemical Engineering, Pennsylvania State University, University Park, PA, USA.

\section{Competing interests}

The authors declare that they have no competing interests.

\section{Ethical approval}

This article does not contain any studies with human participants or animals performed by any of the authors.

\section{Funding}

This research was supported by a National Research Foundation of Korea (NRF) grant funded by the Korea government (MSIP) (\#2015R1A2A2A01004542 to J. Lee), by the Basic Science Research Program through the NRF funded by the Ministry of Education (\#215C000232 to J-H. Lee), and by the Priority Research Centers Program through the NRF funded by the Ministry of Education (\#2014R1A6A1031189).

Received: 24 November 2016 Accepted: 27 November 2016 Published online: 05 December 2016

\section{References}

Bansal T, Alaniz RC, Wood TK, Jayaraman A (2010) The bacterial signal indole increases epithelial-cell tight-junction resistance and attenuates indicators of inflammation. Proc Natl Acad Sci USA 107:228-233. doi:10.1073/ pnas.0906112107

Brown ML, Gauthier JJ (1993) Cell density and growth phase as factors in the resistance of a biofilm of Pseudomonas aeruginosa (ATCC 27853) to iodine. Appl Environ Microbiol 59:2320-2322

Bunders CA, Minvielle MJ, Worthington RJ, Ortiz M, Cavanagh J, Melander C (2011) Intercepting bacterial indole signaling with flustramine derivatives. J Am Chem Soc 133:20160-20163. doi:10.1021/ja209836z

Calvori C, Frontali L, Leoni L, Tecce G (1965) Effect of rifamycin on protein synthesis. Nature 207:417-418. doi:10.1038/207417a0

Cegelski L, Marshall GR, Eldridge GR, Hultgren SJ (2008) The biology and future prospects of antivirulence therapies. Nat Rev Microbiol 6:17-27. doi:10.1038/nrmicro1818

Conlon BP, Nakayasu ES, Fleck LE, LaFleur MD, Isabella VM, Coleman K, Leonard SN, Smith RD, Adkins JN, Lewis K (2013) Activated ClpP kills persisters and eradicates a chronic biofilm infection. Nature 503:365-370. doi:10.1038/ nature 12790

Costerton JW, Stewart PS, Greenberg EP (1999) Bacterial biofilms: a common cause of persistent infections. Science 284:1318-1322. doi:10.1126/ science.284.5418.1318

Erb M, Veyrat N, Robert CA, Xu H, Frey M, Ton J, Turlings TC (2015) Indole is an essential herbivore-induced volatile priming signal in maize. Nat Commun 6:6273. doi:10.1038/ncomms7273

Heydorn A, Nielsen AT, Hentzer M, Sternberg C, Givskov M, Ersboll BK, Molin S (2000) Quantification of biofilm structures by the novel computer program COMSTAT. Microbiology 146:2395-2407. doi:10.1099/00221287-146-10-2395

Hoffman LR, D'Argenio DA, MacCoss MJ, Zhang Z, Jones RA, Miller SI (2005) Aminoglycoside antibiotics induce bacterial biofilm formation. Nature 436:1171-1175. doi:10.1038/nature03912

Hu Y, Kwan BW, Osbourne DO, Benedik MJ, Wood TK (2015) Toxin YafQ increases persister cell formation by reducing indole signalling. Environ Microbiol 17:1275-1285. doi:10.1111/1462-2920.12567

Keren I, Kaldalu N, Spoering A, Wang Y, Lewis K (2004) Persister cells and tolerance to antimicrobials. FEMS Microbiol Lett 230:13-18. doi:10.1016/ S0378-1097(03)00856-5
Kim Y-G, Lee J-H, Cho MH, Lee J (2011) Indole and 3-indolylacetonitrile inhibit spore maturation in Paenibacillus alvei. BMC Microbiol 11:119. doi:10.1186/1471-2180-11-119

Kim Y-G, Lee J-H, Kim CJ, Lee J-C, Ju YJ, Cho MH, Lee J (2012) Antibiofilm activity of Streptomyces sp. BFI 230 and Kribbella sp. BFI 1562 against Pseudomonas aeruginosa. Appl Microbiol Biotechnol 96:1607-1617. doi:10.1007/s00253-012-4225-7

Kwan BW, Valenta JA, Benedik MJ, Wood TK (2013) Arrested protein synthesis increases persister-like cell formation. Antimicrob Agents Chemother 57:1468-1473. doi:10.1128/AAC.02135-12

Kwan BW, Osbourne DO, Hu Y, Benedik MJ, Wood TK (2015) Phosphodiesterase DosP increases persistence by reducing CAMP which reduces the signal indole. Biotechnol Bioeng 112:588-600. doi:10.1002/bit.25456

Lee J-H, Lee J (2010) Indole as an intercellular signal in microbial community. FEMS Microbiol Rev 34:426-444. doi:10.1111/j.1574-6976.2009.00204.x

Lee J, Jayaraman A, Wood TK (2007) Indole is an inter-species biofilm signal mediated by SdiA. BMC Microbiol 7:42. doi:10.1186/1471-2180-7-42

Lee J, Attila C, Cirillo SLG, Cirillo JD, Wood TK (2009) Indole and 7-hydroxyindole diminish Pseudomonas aeruginosa virulence. Microbial Biotech 2:75-90. doi:10.1111/j.1751-7915.2008.00061.x

Lee HH, Molla MN, Cantor CR, Collins JJ (2010) Bacterial charity work leads to population-wide resistance. Nature 467:82-85. doi:10.1038/nature09354

Lee J-H, Cho MH, Lee J (2011) 3-Indolylacetonitrile decreases Escherichia coli 0157:H7 biofilm formation and Pseudomonas aeruginosa virulence. Environ Microbiol 13:62-73. doi:10.1111/j.1462-2920.2010.02308.x

Lee J-H, Kim Y-G, Cho MH, Kim J-A, Lee J (2012) 7-Fluoroindole as an antivirulence compound against Pseudomonas aeruginosa. FEMS Microbiol Lett 329:36-44. doi:10.1111/j.1574-6968.2012.02500.x

Lee J-H, Cho HS, Kim Y-G, Kim J-A, Banskota S, Cho MH, Lee J (2013) Indole and 7-benzyloxyindole attenuate the virulence of Staphylococcus aureus. Appl Microbiol Biotechnol 97:4543-4552. doi:10.1007/s00253-012-4674-z

Lee J-H, Kim Y-G, Baek KH, Cho MH, Lee J (2015) The multifaceted roles of the interspecies signalling molecule indole in Agrobacterium tumefaciens. Environ Microbiol 17:1234-1244. doi:10.1111/1462-2920.12560

Levy SB, Marshall B (2004) Antibacterial resistance worldwide: causes, challenges and responses. Nat Med 10:S122-S129. doi:10.1038/nm1145

Lewis K (2007) Persister cells, dormancy and infectious disease. Nat Rev Microbiol 5:48-56. doi:10.1038/nrmicro1557

Lewis K (2008) Multidrug tolerance of biofilms and persister cells. Curr Top Microbiol Immunol 322:107-131. doi:10.1007/978-3-540-75418-3_6

Lewis K (2010) Persister cells. Annu Rev Microbiol 64:357-372. doi:10.1146/ annurev.micro.112408.134306

Linares JF, Gustafsson I, Baquero F, Martinez JL (2006) Antibiotics as intermicrobial signaling agents instead of weapons. Proc Natl Acad Sci USA 103:19484-19489. doi:10.1073/pnas.0608949103

Maeda T, Garcia-Contreras R, Pu M, Sheng L, Garcia LR, Tomas M, Wood TK (2012) Quorum quenching quandary: resistance to antivirulence compounds. ISME J 6:493-501. doi:10.1038/ismej.2011.122

Marques CN, Morozov A, Planzos P, Zelaya HM (2014) The fatty acid signaling molecule cis-2-decenoic acid increases metabolic activity and reverts persister cells to an antimicrobial-susceptible state. Appl Environ Microbiol 80:6976-6991. doi:10.1128/AEM.01576-14

Oh S, Go GW, Mylonakis E, Kim Y (2012) The bacterial signalling molecule indole attenuates the virulence of the fungal pathogen Candida albicans. J Appl Microbiol 113:622-628. doi:10.1111/j.1365-2672.2012.05372.x

Rachid S, Ohlsen K, Witte W, Hacker J, Ziebuhr W (2000) Effect of subinhibitory antibiotic concentrations on polysaccharide intercellular adhesin expression in biofilm-forming Staphylococcus epidermidis. Antimicrob Agents Chemother 44:3357-3363. doi:10.1128/AAC.44.12.3357-3363.2000

Seyfried PL, Fraser DJ (1980) Persistence of Pseudomonas aeruginosa in chlorinated swimming pools. Can J Microbiol 26:350-355. doi:10.1139/m80-057

Vega NM, Allison KR, Khalil AS, Collins JJ (2012) Signaling-mediated bacterial persister formation. Nat Chem Biol 8:431-433. doi:10.1038/nchembio.915

Vega NM, Allison KR, Samuels AN, Klempner MS, Collins JJ (2013) Salmonella typhimurium intercepts Escherichia coli signaling to enhance antibiotic tolerance. Proc Natl Acad Sci USA 110:14420-14425. doi:10.1073/ pnas.1308085110

Wang X, Wood TK (2011) Toxin-antitoxin systems influence biofilm and persister cell formation and the general stress response. Appl Environ Microbiol 77:5577-5583. doi:10.1128/AEM.05068-11 
Weston SA, Parish CR (1990) New fluorescent dyes for lymphocyte migration studies. Analysis by flow cytometry and fluorescence microscopy. J Immunol Methods 133:87-97. doi:10.1016/0022-1759(90)90322-M
Wood TK (2016) Combatting bacterial persister cells. Biotechnol Bioeng 113:476-483. doi:10.1002/bit.25721

Wood TK, Knabel SJ, Kwan BW (2013) Bacterial persister cell formation and dormancy. Appl Environ Microbiol 79:7116-7121. doi:10.1128/AEM.02636-13
Submit your manuscript to a SpringerOpen ${ }^{\circ}$ journal and benefit from:

- Convenient online submission

- Rigorous peer review

Immediate publication on acceptance

- Open access: articles freely available online

- High visibility within the field

- Retaining the copyright to your article

Submit your next manuscript at $>$ springeropen.com 